ISSN : $2620-4665$ (print)

ISSN : 2620 - 4673 (online)

Website : http://jurnal.untan.ac.id/index.php/JPLP2KM

\title{
PEMANFAATAN RESIDU DAGING IKAN GABUS (Channa Striata) UNTUK PEMBUATAN COOKIES MAKANAN BALITA DI KECAMATAN BUKIT BATU KOTA PALANGKARAYA
}

\author{
Firlianty ${ }^{1^{*}}$, Muhamad Noor Yasin ${ }^{2}$, Anang Najamuddin ${ }^{3}$ \\ 1,2,3 Universitas Palangkaraya \\ email: firly_thp@fish.upr.ac.id
}

\begin{abstract}
ABSTRAK
Residu adalah sisa bahan yang tidak terpakai. Hasil residu ada yang berupa bahanbahan tidak terpakai yang akan dibuang lagi, namun ada juga yang bisa di recycle atau dengan kata lain dapat dimanfaatkan lagi sehingga bisa lebih efisien. Ikan gabus sangat kaya akan albumin, salah satu jenis protein penting. Albumin diperlukan tubuh manusia setiap hari, ikan tersebut memiliki protein yang sangat tinggi, ikan ini merupakan sumber albumin bagi penderita hipoalbumin (rendah albumin) dan luka. Baik luka pasca operasi maupun luka bakar. Bahkan, di daerah pedesaan, anak laki-laki pasca khitan selalu dianjurkan mengkonsumsi ikan jenis ini agar penyembuhan lebih cepat. Caranya, daging ikan tersebut dikukus atau disteam sehingga memperoleh filtrat, yang dijadikan menu ekstra bagi penderita hipoalbumin dan luka. Dalam tubuh manusia, albumin (salah satu fraksi protein) disintesis oleh hati kira-kira 100-200 mikrogram/g jaringan hati setiap hari.

Albumin merupakan protein utama dalam plasma darah, terdapat dengan jumlah sebesar $40 \%$ sampai $60 \%$ sisanya terdapat pada rongga luar sel. Berperan penting menjaga tekanan osmotik plasma, mengangkut molekul-molekul kecil melewati plasma maupun cairan ekstrasel serta mengikat obat-obatan. Albumin ikan gabus memiliki kualitas jauh lebih baik dari albumin telur yang biasa digunakan dalam penyembuhan pasien pasca bedah. Ikan gabus sendiri, mengandung 6,2\% albumin dan 0,001741\% Zn dengan asam amino esensial yaitu treonin, valin, metionin, isoleusin, leusin, fenilalanin, lisin, histidin, dan arginin, serta asam amino non-esensial seperti asam aspartat, serin, asam glutamat, glisin, alanin, sistein, tiroksin, hidroksilisin, amonia, hidroksiprolin dan prolin.
\end{abstract}

Kata Kunci : Ikan Gabus, Cookies

\section{PENDAHULUAN}

Potensi lestari perikanan laut Indonesia diperkirakan sebesar 6,4 juta ton per tahun yang tersebar di perairan wilayah Indonesia dan ZEE (Zona Ekonomi Ekslusif) dengan jumlah tangkapan yang diperbolehkan sebesar 5,12 juta ton pertahun atau sekitar 80 persen dari potensi lestari. Potensi sumberdaya perikanan yang dimiliki Indonesia tersebut dan produksi yang dihasilkannya menunjukkan bahwa perikanan memiliki potensi yang baik untuk kontribusi di dalam pemenuhan gizi masyarakat, khususnya protein hewani, disamping kontribusinya dalam pertumbuhan perekonomian Indonesia (Irianto dan Soesilo, 2007). 
Albumin merupakan protein utama dalam plasma darah, terdapat dengan jumlah sebesar 40\% sampai 60\% sisanya terdapat pada rongga luar sel (Murray et al., 1993). Albumin mempunyai dua fungsi utama yaitu mengangkut molekul-molekul kecil melewati plasma dan cairan sel serta memberi tekanan osmotik didalam kapiler (Montgomery et al., 1993).

Untuk mendapatkan albumin dari ikan family channidae dapat dilakukan dengan mengekstraknya. Menurut Nina (2006), ekstrak ikan family channidae dapat diartikan sebagai suatu substansi (cairan) atau jaringan yang keluar dari jaringan ikan family channidae selama pemrosesan dan telah melalui alat penyaringan. Ekstrak ikan family channidae berwarna kekuningan dan putih keruh, dihasilkan dari pengukusan daging ikan family channidae segar. Ekstrak ikan family channidae dijadikan sebagai menu ekstra bagi penderita luka baik luka pasca operasi maupun luka bakar.

Cookies yang dikenal juga dengan nama biskuit, merupakan salah satu jenis produk yang mempunyai kadar air sangat rendah dan umumnya mengandung lemak dan gula tinggi (Prasetya, 1988). Umumnya saat ini cookies kebanyakan dikonsumsi oleh orang dewasa karena memiliki daya tarik yang cukup disukai khususnya oleh wanita. Disamping teksturnya yang agak keras dan lebih memberikan rasa kenyang dari banyaknya kandungan lemak yang ada didalam cookies tersebut. Tidak hanya orang dewasa yang dapat mengkonsumsi cookies, bayi dan balita pun dapat mengkonsumsinya karena baik untuk pertumbuhan bayi maupun balita. Tekstur cookies juga berbeda dengan yang dikonsumsi oleh orang dewasa. Cookies untuk bayi maupun balita umumnya mempunyai tekstur yang tidak keras saat dimakan atau bila dicampur dengan air akan menjadi lembut (Depkes, 2007). Di pasaran telah dijumpai produk cookies untuk balita antara lain Promina yang diproduksi PT. Sari Husada dan Milna yang diproduksi PT. Nestle Indonesia, yang semuanya berbahan baku terung terigu.

Beras tercatat mempunyai sifat nonalergenik (tidak menimbulkan alergi), sehingga beras dijadikan sebagai serealia pertama yang dianjurkan untuk makanan bayi (Juliano, 1985) dan untuk menentukan penyakit alergi terhadap serealia lain yang spesifik, misalnya terigu. Penderita intoleran protein terigu sangat bergantung pada beras sebagai sumber karbohidrat (Bean et al., 1983).

Kegiatan ini akan dilakukan dengan pembinaan langsung terhadap mitra usaha binaan bagi lbu -ibu Rumah Tangga di Kecamatan bukit batu melalui penyuluhan, diskusi, bimbingan serta praktek langsung tentang permen coklat dari Ikan Family Channidae. Kegiatan ini nantinya 
ISSN : $2620-4665$ (print)

ISSN : 2620 - 4673 (online)

Website : http://jurnal.untan.ac.id/index.php/JPLP2KM

diharapkan dapat meningkatkan pengetahuan dan keterampilan ibu-ibu Rumah Tangga dalam berusaha mengolah potensi perikanan khususnya ikan lokal secara kontinyu yang tentunya mempunyai pengaruh besar terhadap perekonomian/penghasilan dan kesejahteraan ibu-ibu Rumah Tangga itu sendiri sehingga bisa menjadi salah satu ciri khas olahan Kalimantan Tengah.

\section{METODE PELAKSANAAN}

Pelaksanaan kegiatan pengabdian ini berupa demonstrasi atau memberikan praktek langsung tentang cara mengolah cookies dari ikan lokal. Dalam demonstrasi ini juga diberikan kesempatan tanya jawab dengan peserta. Gambaran IPTEKS yang akan ditransfer kepada masyarakat (ibu-ibu RT dan remaja putri) adalah berupa :

a. Meningkatnya ketrampilan masyarakat (ibu-ibu RT dan remaja putri) dalam mengolah hasil perikanan terutama cookies dari ikan lokal air tawar.

b. Meningkatnya kreativitas dan innovasi masyarakat (ibu-ibu RT dan remaja putri) dalam menciptakan menu dari produk perikanan berupa cookies dari ikan air tawar.

c. Melatih masyarakat (ibu-ibu RT dan remaja putri) untuk dapat menciptakan menu olahan produk ikan lokal.

\section{HASIL DAN PEMBAHASAN}

Kue kering yang juga sering disebut cookies berasal dari kata koekie yang artinya small cake. Bahan dan cara pembuatan kue kering memang tidak jauh beda dengan cara membuat cake. Meskipun begitu, di Indonesia cookies disebut kue kering karena rasanya yang memang renyah dan kering. Membuat kue kering sekilas tampaknya amat mudah. Semua bahan dicampur lalu dibentuk dan dioven. Padahal prosesnya tidak semudah itu. Ada beberapa hal yang perlu diketahui dan dilakukan agar kue kering tidak sekadar jadi, tetapi enak rasanya. Pemahaman bahan dan karakternya akan membantu menciptakan kue kering yang lezat. Teknik pembuatan kue juga akan banyak menolong saat menemukan kegagalan waktu membuat kue kering (Kristine, 2010).

Berdasarkan hasil kajian SNI biskuit atau cookies, SNI 01-2973-1992, diperoleh bahwa parameter yang diusulkan untuk dipersyaratkan pada SNI berikutnya adalah keadaan meliputi bau, rasa, dan warna, kadar air, kadar protein, kadar lemak, asam lemak bebas dan bilangan peroksida. Cemaran logam dan cemaran mikroba menyesuaikan dengan persyaratan 
Peraturan Kepala Badan Pengawas Obat dan Makanan Republik Indonesia No. HK.00.06.1.52.4011 Tahun 2009 tentang Penetapan Batas Maksimum Cemaran Mikroba dan Kimia dalam Makanan (Wijaya dan Nirwana, 2010).

Tabel 1. Kadar Proksimat dan Albumin pada Ikan Gabus

\begin{tabular}{|c|c|c|c|c|c|c|}
\hline \multirow[b]{2}{*}{ No. } & \multirow[b]{2}{*}{ Komposisi } & \multicolumn{5}{|c|}{ Parameter } \\
\hline & & $\begin{array}{c}\text { Albumin } \\
(\%)\end{array}$ & $\begin{array}{c}\text { Protein } \\
(\%)\end{array}$ & $\begin{array}{c}\text { Lemak } \\
(\%)\end{array}$ & $\begin{array}{l}\text { Air } \\
(\%)\end{array}$ & $\begin{array}{l}\text { Abu } \\
(\%)\end{array}$ \\
\hline & Daging segar & 5,97 & 17,30 & 1,75 & 47,46 & 1,87 \\
\hline 2. & Kulit & 0,67 & 4,35 & 0,75 & 38,40 & 2,40 \\
\hline 3. & Kepala dan tulang & 0,21 & 0,87 & 0,40 & 31,85 & 4,20 \\
\hline
\end{tabular}

Sumber : Firlianty et al, 2013
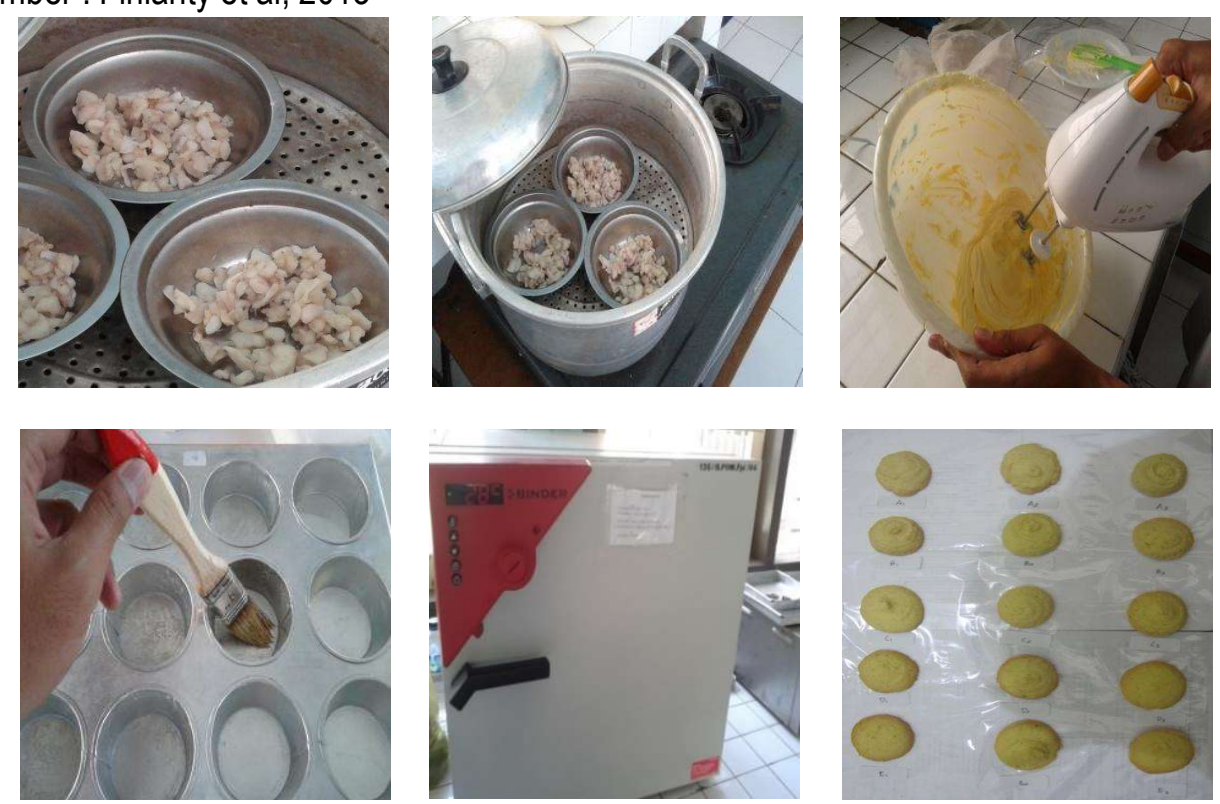

Gambar 1. Hasil Kegiatan Program Kemitraan Wilayah Sosialisasi

Konsumsi ikan gabus sebaiknya mulai dibiasakan sejak balita. Pemberian makanan yang kaya albumin ini bukan hanya dilakukan ketika anak menunjukkan gejala sakit, tetapi juga ketika sehat. Hal tersebut berkaitan dengan fungsi albumin yang sangat penting. Sebuah penelitian yang dilakukan Ida Samidah dari Balitbangda Sulawesi Selatan menunjukkan, balita yang mengonsumsi ikan gabus secara teratur memiliki kadar albumin jauh lebih tinggi dibandingkan dengan balita yang tidak mengonsumsinya. Selain itu, balita yang mengonsumsi ikan gabus secara teratur juga mengalami peningkatan berat badan dan kadar hemoglobin darah secara nyata. Di pasaran, ikan gabus lebih banyak dijual dalam keadaan kering dan sudah diasinkan. Namun, tidak sedikit pula ikan gabus dijual dalam 
ISSN : $2620-4665$ (print)

ISSN : $2620-4673$ (online)

Website : http://jurnal.untan.ac.id/index.php/JPLP2KM

keadaan segar. Ikan gabus kering atau dalam keadaan masih segar mempunyai khasiat yang sama bagi kesehatan. Hal yang perlu dicermati pada ikan gabus kering asin adalah kadar natriumnya yang tinggi. Natrium tersebut berasal dari garam dapur (natrium klorida) yang digunakan untuk mengasinkan ikan. Konsumsi natrium tinggi akan menyebabkan seseorang mudah mengalami hipertensi. Karena itu, penderita tekanan darah tinggi disarankan untuk mengonsumsi ikan gabus segar. Upaya sederhana untuk mengurangi kadar natrium pada ikan gabus kering asin adalah dengan cara merendamnya dalam larutan garam encer, selama beberapa jam sebelum diolah lebih lanjut. Dengan perendaman tersebut, garam dari konsentrasi tinggi (pada ikan asin) akan mengalir menuju konsentrasi rendah (larutan garam encer), sehingga kadar garam pada ikan turun (Intisari Herbal, 2011).

\section{SIMPULAN DAN SARAN}

\section{KESIMPULAN}

Kegiatan yang telah dilaksanakan dapat diaplikasikan pada masyarakat mitra sehingga masyarakat mitra dapat mengolah hasil perikanan menjadi produk pangan yang memiliki gizi yang tinggi dan dapat disukai masyarakat. Dapat disimpulkan dari kegiatan yang sudah dilaksanakan adalah sebagai berikut :

1. Kegiatan yang dilaksanakan dapat menambah pengetahuan mitra dalam diversifikasi pembuatan produk-produk hasil perikanan terutama ikan gabus yang keberadaannya banyak di Kota Palangkaraya.

2. Mitra memiliki ketrampilan dalam mengolah cookies dari ikan gabus

\section{SARAN}

Hubungan kemitraan antara masyarakat dan akademisi sebaiknya terjalin dengan kegiatan pengabdian yang dilakukan antara masyarakat dan pihak akademisi secara berkesinambungan, sehingga keterampilan yang didapatkan mitra dapat meningkatkan kesejahteraan masyarakat mitra baik untuk nilai ekonomi maupun nilai kesehatan. 


\section{DAFTAR PUSTAKA}

Aprianto. A.D. Fardias, N.L, Puspita Sari. S. Bidianto. 1989. Petunjuk Laboratorium Analisa Pangan. IPB. Bogor.

Anonymous.2013. Gula Halus.http//asiamaya. Com. Diakses tanggal 11 Mei .2017. .2013. Mentega. http//Loetfiek.blgspot.cm. Diakses tanggal 11 Mei .2017.

Broekel, R. 1982. The Great American Candy Bar Book. Houghton Mifflin co., USA.

Buckle KA, Edwards RA, Fleet GH, Wotton M. 1981. Ilmu Pangan. Terjemahan oleh Purnomo H, Adiono. Jakarta. UI Press.

Carvalho. 1998. Studi Profil Asam Amino, Albumin dan Seng Pada Ikan family channidae (Ophiocephalus sriatus) dan Ikan Tomang (Ophiocephalus micropeltes). Skripsi. Fakultas Perikanan. Universitas Brawijaya. Malang.

Cholik, F.,Ateng G.,J.Purnomo R.P.,dan Ahmad J. 2005. Akuakultur. PT.Victoria Kreasi Mandiri. Jakarta.

Charley, H. 1982. Food Science. Oregor State University.John Willey and Sons. New York.

Ciptarini, D. A. dan N. Diastuti. 2006. Ekstraksi Crude Albumin dari Ikan family channidae(Ophiocephalus striatus) dengan Menggunakan Ekstraktor Vakum. Politeknik Negeri Malang. Malang.

Coultate, T.P. 1999. Food The Chemistry of Its Components Third Edition Royal Society of Chemistry. Combridge.

Daneswari,2010. Mentega Lebih Baik Dari Margarin.httphttp://ilmu gizi.com diakses pada tanggal 27 Maret 2016 pukul 10.03 WIB

Departemen Kesehatan RI. 1967. Daftar Komposisi Bahan Makanan. Jakarta.

Direktorat Jenderal Pengolahan dan Pemasaran Hasil Perikanan. 2010. Bagusnya Ikan Toman. Warta Pasar ikan Edisi Oktober 2010 Volume 86 Halaman 4.

Departemen Kelautan dan Perikanan. 2010. Potensi Tersembunyi, Wild Fresh Water Fish. Direktorat Jenderal Perikanan Tangkap. Jakarta

De Noon, D. .2003. Dark Chocolate is Healthy Chocolate.http // Medical news.com. Diakses tanggal 14 November .2013.

Djuanda,T. 1981. Dunia Ikan. Dumico. Bandung. 
ISSN : $2620-4665$ (print)

ISSN : $2620-4673$ (online)

Website : http://jurnal.untan.ac.id/index.php/JPLP2KM

Dorey dan Draves. 1998. Spectrophotometric Determination of Human Serum Albumin. University of Central Arkansas. Department of Chemistry Conway, AR 72035.

Duffy, SJ and Vita, JA. Effect of Phenolics on Vaskular Endotiphical Funcion. California. USA.

Edward,J.S. 1999. Antioksidant From Cacao.of Agriculture and Food Chemistry 46-55. Florida. USA.

Erinda, R. 2009. Efek Minyak Atsiri Dari Bawang Putih Terhadap Kadar Albumin Plasma Pada Tikus Yang Diberi Diet Kuning Telur. Universitas Diponegoro. Semarang.

Firlianty, Eddy Suprayitno, Happy Nursyam, Hardoko, and Annasari Mustafa. 2013. Chemical Composition and Amino Acid Profile of Channidae Collected FromCentral Kalimantan, Indonesia

Gaman, P.M dan Sherington, K.B. 1992. IImu Pangan : Pengantar IImu Pangan, Nutrisi dan Mikrobiologi Edisi Kedua. Gadjah Mada UP.Yogyakarta.

Glosary.2010. Gula Halus. http://www.trymasak.my/view-glossary.php.Diakses pada tanggal 9 Mei 2016 pukul 13.30 WIB

Harris and Karmas. 1989. Scienties Of Food and Food Tecnology For Health. USA. 